\title{
WAR, SEX, AND DEATH: FROM REPUBLIC TO EMPIRE
}

\author{
Nathan Rosenstein
}

The last dozen years have seen the emergence of a vigorous debate over the demography of the Roman Republic. In 1994 Elio Lo Cascio published the opening salvo in what would become a sustained attack on the communis opinio, the interpretation of the Augustan census figures formulated by Julius Beloch in Die Bevölkerung der römischen Welt and vigorously defended by Peter Brunt in Italian Manpower. Bringing a powerful historiographic analysis and a more sophisticated quantitative methodology to bear, Lo Cascio argued that the census tallies recorded for the reign of Rome's first emperor do not, as Beloch and Brunt held, represent all Roman citizens - men, women, and children - but only adult males, making the total free population of Italy much higher than the roughly five to seven-and-a-half million Beloch and Brunt had estimated. Therefore, rather than declining over the two centuries since $225 \mathrm{BC}$, as Beloch and Brunt concluded, Italy's free population must have been growing vigorously during this period. In subsequent articles Lo Cascio has extended this analysis, arguing for a free population of at least thirteen million by $28 \mathrm{BG}$. His challenge has in turn provoked responses from a number of other scholars, including Neville Morley, Walter Scheidel, and Luuk de Ligt. These last two have made the most recent contributions to the debate, each independently offering new arguments that the free Italian population was not expanding as greatly as Lo Cascio claims but remained stable or was growing only slightly over the last two centuries of the Republic. However, their studies will by no means be the last word in this controversy, and it is to be expected that Lo Cascio will present a vigorous defense of his position in a forthcoming monograph. ${ }^{1}$

${ }^{1}$ E. Lo Cascio, 'The Size of the Roman Population: Beloch and the Meaning of the Augustan Census Figures.' Fournal of Roman Studies 84 (1994), 23-40; J. Beloch, Die Bevölkerung der griechisch-römischen Welt. Historische Beiträge zur Bevölkerungslehre (Leipzig 1886); P.A. Brunt, Italian Manpower 225 BC-AD 14 (London 1971); E. Lo Cascio, 'Popolazione e risorse agricole nell'Italia del II secolo a.C', in D. Vera, ed., Demografia, sistemi agrari, regimi alimentari nel mondo antico (Bari 1999), 217-240; E. Lo Cascio, 'The population of Roman Italy in Town and Country,' in J. Bintliff and K. Sbonias, eds., Reconstructing 
This debate is about much more than mere numbers. It concerns the dynamics of Italy's population: was it growing or declining and in either case, why and how? As is well known, Brunt's interpretation of the census figures rests on a powerful argument about the effects of Roman warfare and the Republic's acquisition of an empire on Italy's economy and society during the second and first centuries BC. The Republic's grinding struggle against Hannibal and the long wars abroad that followed required the conscription of great numbers of Roman and Italian small farmers for many years and so deprived their farms of vital labor. These wars thus ruined the Italian peasantry and forced them off their lands. At the same time, the prisoners these soldiers captured during the city's wars flooded onto the slave markets of Italy. Land and labor abounded, therefore. Money, too, flowed into the purses of Rome's political elite from the spoils of its victorious wars. Lacking other productive outlets for their capital, aristocrats invested in farms worked by slaves producing the wine, oil, grain and other products required to feed the peninsula's urban population, particularly Rome's, which the influx of displaced farmers streaming in from the countryside at that time engorged. Lacking land or other secure means of supporting a family, members of the urban proletariat and their rural brethren were unable to marry and father children or were forced to expose those that were born, leading to the decline in the free population reflected in the Augustan census figures as Brunt interpreted them. ${ }^{2}$

It will come as no surprise to most readers that much of this reconstruction is now facing serious challenges on a number of fronts. Even as Brunt was publishing Italian Manpower, Martin Frederiksen had pointed out that the widespread disappearance of small farms and their replacement by large estates in the second century finds little support in the archaeological record. The slave-run villa, the hallmark

Past Population Trends in Mediterranean Europe (3000 BC-AD 1800) (Oxford 1999), 161-171; E. Lo Cascio, 'Recruitment and the Size of the Roman Population from the Third to the First Century всE,' in W. Scheidel, ed., Debating Roman Demography (Leiden 2001), 111-137; N. Morley, 'The Transformation of Italy, 225-28 вс,' Journal of Roman Studies 91 (2001), 50-62; W. Scheidel, 'Human Mobility in Roman Italy I: The Free Population,' Fournal of Roman Studies 94 (2004), 1-26; W. Scheidel, 'Human Mobility in Roman Italy II: The Slave Population.' Journal of Roman Studies 95 (2005), 64-79; L. de Ligt, 'Poverty and Demography: The Case of the Gracchan Land Reforms.' Mnemosyne 57 (2004), 725-757.

${ }^{2}$ Brunt 1971, op. cit. (n. 1); discussion and references to additional scholarship in N. Rosenstein, Rome at War. Farms, Families, and Death in the Middle Republic (Chapel Hill 2004), 3-6. 
of the so-called 'slave mode of production' is largely a first-century phenomenon, appearing many decades after the events in the second century that are supposed to have brought about its rise. ${ }^{3}$ Likewise, the introduction of the Dressel type 1 amphora, which is closely linked to the great increase in Italian wine production that is usually associated with the rise of slave-run estates, is no earlier than the last third of the second century. ${ }^{4}$ Rather than accepting the common view that commercial, slave-run plantations and small farms constituted antithetical economic forms, Dominic Rathbone in an important article emphasized the dependence of the former on a neighboring network of the latter to meet their needs for labor during periods of peak demand. ${ }^{5}$ Wim Jongmann has lately shown that even at its greatest extent the population of Rome and Italy's other cities would have needed the produce of a minute fraction of Italian agricultural land, on the order of a mere 2 percent, to meet its demand for wine and oil. Even were we to suppose that these cities drew their grain exclusively from Italian farms during the Empire, which is quite unlikely, that would have required no more that 15 percent of the peninsula's crop land. ${ }^{6}$ Walter Scheidel and Luuk de Ligt have each used these figures as the basis for a radical revision downward of estimates of the number of slaves in Italy. ${ }^{7}$ It is no longer possible to suppose, as Brunt and Keith Hopkins did, that the servile portion of the Italian population ever reached two or three million out of a total population of six or seven-and-a-half million in the age of Augustus and displaced much of the free population on the land. ${ }^{8}$ Approaching the problem from a different perspective, John Rich conclusively refuted the claim that the proportion of assidui among the citizen body was declining during the late third and second centuries,

${ }^{3}$ M. Frederiksen, 'The contribution of archaeology to the agrarian problem in the Gracchan period,' Dialoghi di Archeologia 4-5 (1970-1971), 330-357; E. Curti, E. Dench, and J.R. Patterson, 'The Archaeology of Central and Southern Roman Italy: Recent Trends and Approaches,' Journal of Roman Studies 86 (1996), 170-189.

${ }^{4}$ See Rosenstein 2004, op. cit. (n. 2), 195 n. 14 for modern discussions.

${ }^{5}$ D. Rathbone, "The Development of Agriculture in the "Ager Cosanus" During the Roman Republic: Problems of Evidence and Interpretation,' Fournal of Roman Studies 71 (1981), 10-23.

${ }_{6}^{6}$ W. Jongman, 'Slavery and the Growth of Rome. The Transformation of Italy in the Second and First Centuries BCE,' in C. Edwards and G. Woolf, eds., Rome the Cosmopolis (Cambridge 2003), 113-115.

7 Scheidel 2005, op. cit. (n. 1); De Ligt 2004, op. cit. (n. 1), 746-747.

${ }^{8}$ Brunt 1971 op. cit. (n. 1), 124; K. Hopkins, Conquerors and Slaves (Cambridge 1978), 7-8, nn. 13-14. 
long seen as evidence of spreading impoverishment among Roman smallholders. ${ }^{9}$ And I have recently tried to show how patterns of family formation worked to obviate potential conflicts between the war and small-scale agriculture for manpower during the middle Republic. ${ }^{10}$

The questions of Italy's population dynamics and their consequences for social and political developments in the late Republic remain very much open, therefore. These are broad and complex problems and a full treatment of them lies well beyond the scope of this paper. Rather, in what follows I will simply attempt to discover what the impact of Rome's acquisition of an empire during the second and first centuries - and in particular the continuous warfare required to win it - might have been on demographic developments in Italy. The answer, it is hoped, will not only contribute to clarifying this problem but also help point the way to a new understanding of the social and economic background to the political developments that roiled the last generation of the Roman Republic.

Demography is about fertility and mortality, births and deaths. ${ }^{11}$ So what can be said about the impact of Rome's acquisition of an empire on these in Republican Italy? As noted earlier, we can no longer unquestioningly accept Brunt's argument that this led to dispossession and impoverishment among Italy's small farmers and so to their failure to reproduce. Although Appian and Plutarch both assert that this was the case, a generation of scholarship has undercut their credibility, and De Ligt in addition has recently pointed out that the assumption that poverty in and of itself leads couples to have fewer children is unwarranted. ${ }^{12}$ Conscription on the contrary under certain conditions can not simply be not detrimental to the families of small farmers but positively advantageous. It is commonly assumed that many if not most of the farms from which the Republic drew its soldiers were quite small, barely sufficient to support the families that worked them. In such circumstances, removing an adult son for military service eased the pressure on the family's economic resources. As a soldier, the son

\footnotetext{
${ }^{9} \mathrm{~J}$. Rich, 'The supposed manpower shortage of the later second century BC,' Historia 32 (1983), 287-331.

${ }_{10}$ Rosenstein 2004, op. cit. (n. 2), 26-106.

${ }^{11}$ On these topics for Rome generally, W. Scheidel, 'Progress and problems in Roman demography' in W. Scheidel, ed., Debating Roman Demography (Leiden, 2001), $32-46$, is fundamental.

12 Plutarch, Tiberius Gracchus 8.1-3; Appian, Bella Civilia 1.7. Rosenstein 2004, op. cit. (n. 2), 3-17 for discussion. De Ligt 2004, op. cit. (n. 1), 748-751.
} 
would be supported by others - either the Roman or Italian taxpayers who supplied the tributum that in many cases funded his stipendium - or the provincials whose taxes also were a prime source for the food that fed Republican armies, or the Republic's enemies whose crops its armies regularly pillaged. The family's farm consequently had fewer mouths to feed. ${ }^{13}$ More importantly for the present question, military service could facilitate family formation. Neolocality - that is, the custom of a newly married couple setting up an independent household separate from either natal family — was typical of most Roman and Italian families. ${ }^{14}$ That practice however required the couple or their natal families to accumulate considerable resources in order to facilitate the creation of a new, independent household. The Republic's successful wars put money into the purses of its soldiers from booty and donatives and from whatever portion of their stipendium they might have been able to save. Although the amounts may not often have been large in absolute terms, we should nevertheless not underestimate the importance of this ready cash to those living in a mainly subsistence economy where most exchange was by barter and market transactions capable of generating cash were few. ${ }^{15}$ Far more important, however, the conquests these soldiers carried out led indirectly to an increase in the amount of land available to them and other Romans and Italians through the creation of new colonial foundations or viritane distributions. In this way, the Republic's warfare enabled some of the sons and daughters of families whose resources would otherwise have been insufficient, especially in land, to marry and begin families of their own, while the out-migration of colonists reduced the competition for farmland among those they left behind. ${ }^{16}$

We cannot forget, however, that the Italian victims of Rome's aggressions would not have benefited in these ways. If they were not enslaved, they often lost land and other resources, making family formation more difficult. Still, there were ameliorating factors. In the short term, much of the land confiscated by Rome from its defeated enemies was not immediately occupied by colonists, allowing it to continue to be used to

13 Rosenstein 2004, op. cit. (n. 2), 79-80.

14 S. Treggari, Roman Marriage (Oxford 1991), 410.

15 W.V. Harris, War and Imperialism in Republican Rome 327-70 BC (Oxford 1979), 103.

${ }^{16}$ On out-migration of free citizens in this period see Scheidel 2005, op. cit. (n. 1). 
support its previous possessors. In the longer term, those Italians whose capitulation had entailed the requirement to become allies of Rome could, as socii, participate in future distributions of conquered land, thus to some extent redressing the loss of their own territory. And the demand for military manpower that their new status as allies brought with it meant that some portion of their young men would be removed for extended periods and fed by Rome, bringing the ally's economic resources somewhat back into balance with its population.

What enabled this scheme to obviate the possible drawbacks of removing so many men from the land for lengthy enlistments is the fact that although citizens (and presumably allies) became liable to conscription at the age of 17 , they typically did not begin to marry in large numbers before their late 20s or early 30s. However, the Romans (and, again, presumably allied cities) rarely drafted men older than the age of 30. When for example the Republic found itself confronting a dire military crisis following the defeat of two of its armies at Arausio in 105, the surviving consul, P. Rutilius Rufus, issued an edict forbidding men over the age of 35 from leaving Italy: even in this emergency, in other words, the Romans did not expect to call up men over this age. ${ }^{17}$ It was this long period in young men's lives between going to war and starting a family that prevented the potentially deleterious consequences of the former from affecting the latter and enabled warfare to help facilitate family formation. ${ }^{18}$

Although this pattern of early military service and late male marriage appears conducive to nuptuality, nuptuality is not identical with fertility. While effective chemical and other forms of contraception did not exist before the modern era, many societies evolved ways of keeping births well below their theoretical maximum. Human beings have an enormous capacity to reproduce. The highest recorded average number of births occurred among North American Hutterites, a religious group practicing early marriage and encouraging large families, among whom women averaged over 10 live births in the mid-twentieth century. ${ }^{19}$ Consequently, social controls develop to restrict births, since reproduction at rates much above replacement level have the potential

${ }^{17}$ Granius Licinianus Reliquiae 33.26-27Cr.

${ }^{18}$ Rosenstein 2004, op. cit. (n. 2), 81-88.

${ }^{19}$ J.W. Eaton and A.J. Mayer, 'The Social Biology of Very High Fertility Among the Hutterites. The Demography of a Unique Population,' Human Biology 25 (1953), 225. 
to raise the population in fairly short order well above the capacity of its economic resources to support it. The methods to limit births include a late age for female first marriage, lengthy breastfeeding of infants, and postpartum taboos on the resumption of intercourse, among others. ${ }^{20}$ Unfortunately, we know very little about the extent to which these or similar practices were employed to keep population numbers under control in Italy during the middle and late Republic. During the first three centuries of the Empire, women seem to have begun to marry mainly between their late teens or early twenties, and it is a fair guess that in the absence of factors that would raise the age of female first marriage women in the second and first centuries BC would have done so at about the same age. ${ }^{21}$ Consequently, women in this period were married during most of their child-bearing years. Furthermore, the fact that Rome's conquests were continually increasing the amount of farmland available to its citizens and allies, at least down to the middle of the second century, suggests that a chronic shortage of land would not have been likely to lead to practices that would severely limit fertility. However, before we can judge the degree to which families were or were not attempting to do so, it is necessary to examine mortality and especially the impact of warfare on it. For obviously the rate at which fertility has to be limited is closely tied to the other half of the demographic equation, namely the rate at which deaths are occurring within a population.

If we can be very certain of one demographic consequence of Roman imperialism, it is that it entailed death on a very substantial scale among soldiers in Rome's armies. Brunt reckoned that about 120,000 male Roman citizens died in the Hannibalic War, of whom 50,000 represent excess deaths beyond those that would have ordinarily occurred within the seventeen year span of the war. ${ }^{22}$ That figure represents about a sixth of the Rome's pre-war citizen population. Using a different methodology, I have calculated that from 200 down to 167 BG roughly between 183,000 and 210,000 Roman and Italian soldiers

\footnotetext{
${ }^{20}$ A. Coale, 'The Decline in Fertility in Europe Since the Eighteenth Century as a Chapter in Human Demographic History,' in A.J. Coale and S. Cotts Watkins, eds., The Decline of Fertility in Europe (Princeton 1986), 8-10; E.A. Wrigley, 'Fertility Strategy for the Individual and the Group' in E.A. Wrigley, People, Cities and Wealth: The Transformation of Traditional Society (Oxford/New York 1987), 264-266.

${ }^{21}$ R. Saller, Patriarchy, Property, and Death in the Roman Family (Cambridge 1994), $36-37$.

${ }^{22}$ Brunt 1971, op. cit. (n. 1), 422.
} 
died fighting the Republic's wars or about 4.8 and 5.5 percent of all conscripts per year. However, the net or excess mortality would have been lower because 1.5 percent of all soldiers serving in the legions or allied forces would have died annually of natural or other causes in the ordinary course of events if they had remained civilians. Subtracting these deaths yields an excess mortality attributable to the wars of this era of about 130,000 to 157,000 deaths or $3.35-3.95$ percent annually of all conscripts. ${ }^{23}$

The calculations by which I have reached these figures are based on the numbers of casualties that Livy sometimes reports for battles in the period 200-167. On that basis I developed a low figure for the Romans' losses in a typical battle for which Livy reports no number of deaths as well as for other, minor engagements along with fairly optimistic estimates of the number of Roman and allied soldiers who were wounded in these battles and the rates at which they survived their wounds. Also critical in my calculations were estimates, again fairly optimistic, of the increased mortality among soldiers due to exposure to diseases and the hardships of military service over normal civilian rates of mortality for their age cohort. Because these assumptions tended to produce the lowest plausible estimates of military mortality, my impression is that the actual rates of death among the soldiers in Rome's armies were considerably higher.

In the years following 167 Roman armies fought many, many battles: during the 140s and 130s in Spain, Greece, Sicily, and Carthage, and thereafter in Gaul, the Balkans, Asia Minor, Sardinia, North Africa, Spain, and Sicily down to the end of the second century. The first century, too, witnessed plenty of combat in Asia Minor, Spain, and Gaul as well as two bloody rounds of civil war between 91 and 81 and again between 49 and 31. In most cases our evidence does not permit us to estimate the severity of this fighting. While it certainly ranged from minor skirmishing against unorganized opponents to long, hard combat against well-trained and highly motivated enemies, how much of each Roman armies experienced cannot be known nor how many battles fell in between these two extremes. Consequently, the methods used for battles from 201 to 167 cannot be applied to fighting in this period. However, a rough sense of the scale of death in these years can

${ }^{23}$ Rosenstein 2004, op. cit. (n. 2), 109-140. 
be obtained by applying the rates of excess military mortality developed for the early decades of the second century to the average numbers of men under arms down to 49 Bc. Between 167 and 91, on average about 91,000 Romans and Italians were serving with the legions every year. ${ }^{24}$ If excess mortality among them ranged between 3.25 and 3.95 percent, this amounted to about 2,960-3,600 deaths beyond normal civilian mortality every year, or about 228,000 to 277,000 total additional deaths over 77 years. Between 79 and 49, Brunt calculated that on average 90,000 men were under arms every year. ${ }^{25}$ At the rates used above, excess mortality again amounted to about 2,900-3,600 deaths per year and totaled $88,000-107,000$ over thirty years. However, fighting in these years may not have been as intense as during the period 201-167 and conditions of service less difficult. If military mortality was only 75 percent of the earlier period, then total losses for the years 167 to 91 were only $2,200-2,700$ per year, totaling $169,000-208,000$ and 2,200-2,700 per year totaling $66,000-80,000$ for $80-49$ Bc. These estimates deliberately leave aside the periods of the greatest mobilization and most intense fighting during the Social War and the civil wars 91-81 and 49-31, when we ought to expect significantly higher rates of military mortality than on average. Nor does it include the Roman disaster at Arausio in 105, when as many as 60,000 Roman and Italian soldiers may have died. ${ }^{26}$

It must be stressed that the calculations offered above cannot pretend to offer anything more than an impression of military mortality in this period. The figures cited above are presented for heuristic purposes only. They simply put in more concrete terms what ought to have been intuitively obvious anyway, namely that a lot of men died in the Republic's wars in the second and first centuries. These deaths were certainly tragic for the families who lost sons in these conflicts, but their consequences were not universally so for the survivors. Deaths on so vast a scale eased pressure on the supply of farmland, not simply because Rome's wars reduced the number of soldiers who would return to civilian life and take up farming once again, but because these deaths meant that fewer men were available to marry women and father children with them. Productivity is also likely to have increased. With less pressure

24 Brunt 1971, op. cit. (n. 1), 426-434.

25 Brunt 1971, op. cit. (n. 1), 448-472.

26 Brunt 1971, op. cit. (n. 1), 685. 
on farmland, areas of marginal fertility are abandoned, and surviving farmers concentrate their efforts on the better land because they have access to more of it. Consequently, the same amount of work on better quality land tends to produce greater yields of the crops grown on it. In addition, whatever market for wage labor existed would have become more favorable to those in a position to supply it. This would have been the case not only in the cities but in the countryside as well, since estates producing cash crops with slave labor depended on hiring temporary free workers from among neighboring small farmers to supplement the permanent servile workforce during periods of peak demand for labor, such as the harvest. As was the case for the survivors of major mortality crises in later eras, such as the Black Death, the prospects for those citizens and Italians whom the Republic's wars did not carry off are likely to have been anything but bleak. ${ }^{27}$

More importantly for the present purposes, prosperity generally tends to lead to population increase. In Russia during the late nineteenth and early twentieth centuries, there was a positive correlation between family wealth and family size. A study comparing the reproductivity of farm families in New England region of the United Sates with that of families in the Western U.S. during nineteenth century found that the abundance of land in the western frontier areas and significant levels of in-migration allowed fathers of families there to expect much higher rates of return on their capital investments in agriculture than their eastern counterparts. They were therefore willing to have more children because they were confident that they could accumulate enough capital to establish a greater number of children on independent farms when they came of age than their counterparts in the East, where equally large profits from farming and land ownership could not be expected. Confirmation of the benign effects military mortality had on fertility in middle Republic comes from the census figures for period after Hannibalic War. Between 203 and 168, the Republic's citizen population grew by about 1.5 percent per year when deaths of soldiers are factored in, while between 203 and 124 it increased by about 1 per cent per

${ }^{27}$ Rosenstein 2004, op. cit. (n. 2), 142-145. 
annum when military mortality is again included. These are very high rates of increase for a pre-industrial population. ${ }^{28}$

This is not to argue that rates of increase this high were sustained over the whole course of the last two centuries of the Republic but only that in order to explain them we need to posit strong factors encouraging fertility among the Roman population during the period 203-124 that produced very high rates of increase despite significant military mortality. In my view, the most plausible explanation lies in the improved economic circumstances and an optimistic outlook among survivors brought about by the high level of death among those conscripted to fight Rome's wars. Moreover, these factors were structural and long-term. Consequently, we ought to expect them to have continued to operate throughout the middle and late Republic, even under circumstances that one might expect to have been strongly detrimental to fertility, for example during the Social or civil wars. Episodes such as these were of limited duration, and the mechanisms allowing for high levels of reproductivity, such as limited breastfeeding and early weaning or women's relatively early ages at first marriage, are very unlikely to have altered significantly in response to them. In other words, despite the political and military shocks of the first century, Roman and presumably Italian families probably kept on producing children at a strong, steady rate that may have varied over time, but is unlikely to have every come fully into balance with rates of mortality from wars and other causes.

The result was a 'high pressure' demographic system in which high fertility was both a cause and an effect of Rome's acquisition of an empire. ${ }^{29}$ On the one hand, a high birthrate among Romans and Italians was necessary simply to sustain the elevated levels of mortality that the Republic's continuous warfare entailed. Without high fertility, Rome's conquests eventually would have ground to a halt as the city ran out of men to fight its wars. On the other hand, this same high

${ }^{28}$ T. Shanin, The Awkward Class; Political Sociology of Peasantry in A Developing Society: Russia 1910-1925 (Oxford 1972), 63-66; R.A. Easterlin, 'Population Change and Farm Settlement in the Northern United States,' The Fournal of Economic History 36 (1976), 45-75; Rosenstein 2004, op. cit. (n. 2), 146-147, compare De Ligt 2004, op. cit. (n. 1), 738-744.

${ }^{29}$ See E.A. Wrigley and R.S. Schofield, The Population History of England 1541-1871: A Reconstruction (Cambridge 1989), xxiv. 
mortality and the conquests it made possible produced conditions that generally enhanced the economic prospects of the survivors, creating the conditions that promoted high fertility within families. War, in other words, brought about fewer marriages overall but enabled those marriages that did occur to produce more children than would have been possible if military mortality had not been substantially reducing the number of thirty year-old men available to begin families, thereby easing the struggle for scarce economic resources among the survivors. Or in Malthusian terms, Roman imperialism resulted in a failure to apply extensive preventive checks upon births and so led to the positive check of war coming into play to limit population growth. How effectively it did so, however, must remain a matter of debate. Under the 'low count' interpretation of the Augustan census figures, war together with disease and out migration was how Italy's population remained essentially flat over the final two centuries of the Republic, despite episodes of high short-term growth. If we follow Lo Cascio's interpretation of the census figures of $28 \mathrm{BC}$ and following, however, those positive checks must appear considerably less effective, and that ineffectiveness in turn makes it much easier to explain how Julius Caesar and Augustus could export some 225,000 citizens from Italy between 48 and 28 BC to colonies overseas. ${ }^{30}$

The end of Republican government and the establishment of Imperial rule raise an equally important question, namely what effect did the military changes that Augustus brought about have on the demographic processes outlined above? In the short-term, the answer is probably very little. Augustus' military establishment numbered 28 legions or about 150,000 legionaries, which represented a larger number of men under arms than during the last years of the Republic prior to the outbreak of civil war in 49. A force this large would have required the enlistment of about 11,000 men each year just to replace those who had died or been discharged over the preceding twelve months. ${ }^{31}$ And as is well known, Augustus fought many wars during his reign. Even following the Verrine disaster of $\mathrm{AD} 9$ and the decision to retrench behind the Rhine frontier, the Romans still made major forays into Germany. We do not for the most part have any way of determining the intensity

\footnotetext{
${ }^{30}$ Brunt 1971, op. cit. (n. 1), 234-264.

31 W. Scheidel, Measuring Sex, Age, and Death in the Roman Empire. Explorations in Ancient Demography (Ann Arbor 1996), 93.
} 
of the fighting that was carried out during all of these campaigns, but certainly major battles must often have occurred with heavy casualties for the Roman forces. Consequently, we might expect the same factors that had affected the demographic regime during the middle and late Republic to have continued to operate with undiminished effect, reducing population pressures on the land and conducing to high fertility in families. Colonization, too, in this period contributed to these same ends. We may perhaps see confirmation of these trends in the census figures preserved for $\mathrm{AD} 47$, which exhibit a rise of over .5 percent per year over the period between AD 14 and 47. Even allowing, with Brunt, that nearly 40 percent of the citizen population was domiciled abroad in the former year and assuming that fully half of the increase in citizen numbers by 48 occurred among those expatriates, the increase in Italy itself still averaged .45 percent per year, which is a vigorous although not exceptional rate for a pre-industrial population. ${ }^{32}$

Over the long term, however, the outlook may not have been so benign. Although Rome's wars certainly did not cease after Augustus, they did become less frequent. More importantly, recruitment from Italy gradually declined over the next century or so until, by the reign of Trajan, only about 30 percent of Roman legionaries came from the peninsula, and the proportion of Italians subsequently grew even smaller. ${ }^{33}$ What, therefore, would have been the result when military mortality came to play a smaller and smaller role in Italy's demographic regime? Were the preventive checks on population growth slowly applied, so that fertility declined more or less in step with the decreasing role of military mortality, so that eventually equilibrium was reached between population growth and Italy's agricultural resources? Or did the absence of preventive checks mean that the structural factors that had bought about high birthrates continue unabated, resulting in continuing population increase, so that Italians gradually became impoverished as their numbers grew beyond the capacity of Italy's agricultural resources to

${ }^{32}$ Numbers of citizens: in AD 14: 4,937,000, Res Gestae Divi Augusti 8.4; in 47: 5,984,072, Tacitus, Annales 11.25. On the latter number see Beloch 1886, op. cit. (n. 1), 371-372. On the proportion of citizens domiciled overseas in AD 14, see Brunt 1971, op. cit. (n. 1), 265.

${ }_{33}$ G. Forni, Il Reclutamento delle Legioni da Augusto a Diocleziano (Milan 1953), 65-75, cf. 177-212; idem, 'Estrazione etnica e sociale dei soldate delle legioni nei primi tre secoli dell'imperio,' in H. Temporini and W. Haase, eds., Aufstieg und Niedergang der Römischen Welt; Geschichte und Kultur Roms im Spiegel der neueren Forschung (Berlin 1972-) 2.1, 381-372. 
support them? Or was emigration the answer, with substantial numbers of men and women forced to leave the countryside to seek opportunities to earn a livelihood either in Italy's cities or abroad? Or perhaps all three processes occurred simultaneously? These are difficult and complex questions, but it is essential that we attempt to answer them if we are to understand, in human terms, the impact of empire on Italy under Imperial rule. 
PART TWO

THE EMPEROR AND HIS FORCES. GENERAL ISSUES 